\title{
Effects of A Health Risk Information Strategy on Risk Perceptions of Diseases Related to Physical Inactivity in Adolescents
}

\author{
Young Ho Kim¹, In Kyung Park' ${ }^{1}$ Soo Jin Kang ${ }^{1 *}$ \\ 'Seoul National University of Science and Technology, Seoul, Korea
}

Received: January 24, 2018

Accepted: April 23, 2018

Published online: April 30, 2018

Keywords:

Adolescent

Health risk information strategy

Risk perception

Physical activity
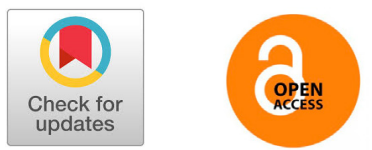

\begin{abstract}
PURPOSE The current study identified effects of the health risk information strategy on risk perception to diseases related to physical inactivity, and test the relationships between changes in risk perception and changes in physical activity.

METHODS A total of 37 adolescents voluntarily participated in the 12-week health risk information strategy. In the initial stage of this study, adolescents were randomly classified into the experimental group and the control group. The experimental group was instructed the health risk information twice a week, while the control group lived a routine life. Health vulnerability, objective risk factors related to physical inactivity, and physical activity were measured to the study variables and $2 \times 2$ repeated measure analysis of variance and hierarchical regression analysis were conducted.

RESULTS Results indicated that the adolescents at health risks related to physical inactivity showed significant increase in risk perception on waist size and BMI after the health risk information strategy. In addition, changes in risk perception on obesity and diabetes significantly influenced on changes in physical activity.

CONCLUSIONS This study implies that it needs to actively promote not only health risks due to physical inactivity, but health benefits of physical activity in order to reduce diseases associated with physical inactivity in health promotion and preventive medicine.
\end{abstract}

(๑) The Asian Society of Kinesiology and the Korean Academy of Kinesiology

\section{서 론}

청소년 건강에 대한 연구보고서에 따르면, 전 세계적으 로 청소년들의 체격은 좋아졌으나, 기본체력은 오히려 저 하되고 있으며, 이러한 현상에 대해 신체활동 부족이 다른 어떤 요인들보다 중요한 원인으로 인식되고 있다(Duncan, Duncan, Strycker, \& Chaumeton, 2007; Seoul City Education Office, 2009). $\operatorname{Kim}(2011)$ 에 따르면, 연구에 참여한 885

*Correspondence: Soo Jin Kang, Seoul National University of Science and Technology, 232 Gongneung-ro, Nowon-gu, Seoul, 01811, Republic of Korea.

E-mail: eostm2000@naver.com
명의 청소년들 중, 약 $16 \%$ 가 전혀 운동을 하지 않는 것으로 나타났으며, 특히 더욱 심각한 것은 신체활동을 한다고 응 답한 청소년들 중 약 $51 \%$ 가 신체활동부족인 것으로 보고 되었다(1회/주: $24 \%, 1$ 회/월: $27 \%)$. 이러한 청소년들의 신 체활동부족은 다른 문화권에서도 유사한 경향을 보이고 있다. 뿐만 아니라, U.S. Center for Disease Control(2012)은 미국청소년들의 신체활동부족 현상은 매우 심각하다고 지적하였다. 이 보고서에서 “신체활동을 전혀 하지 않는 다” 고 응답한 청소년들의 비율이 2010년 약 $28 \%$ 로 2000 년(약 $31 \%$ )에 비해 다소 감소하였지만, 신체활동을 한다 고 응답한 청소년들 중, 약 $39 \%$ 가 일주일 또는 한 달에 1 번 정도 신체활동을 하고 있어 건강을 유지하는데 매우 부족 
한 것으로 나타났다.

이와 같은 청소년들의 운동부족 문제는 운동심리학의 관점에서 “규칙적으로 신체활동을 하지 않는 청소년들 은 자신들이 남들보다 운동부족과 관련된 질병에 걸릴 가 능성을 어떻게 지각하고 있을까?” 라는 의문을 가지게 한다. 질병에 걸릴 위험에 대해 부정확하게 지각하는 것 은 그만큼 건강에 부정적인 영향을 줄 수 있기 때문에, 이 질문에 대한 답을 확인하는 것은 중요하다. 신체활동을 포함한 건강행동에 영향을 주는 인지과정으로써 위험지 각의 개념은 보호동기이론 (protection motivation theory) 을 포함한 건강행동 변화에 관한 여러 이론에서 중요한 개념으로 지적되고 있다(Rogers, 1983). 보호동기이론은 사람들이 부정적인 건강행동 결과의 위험지각이 높을 때 건강을 보호하는 행동을 할 가능성이 더 높다고 가정된 다. 즉 이 이론은 건강보호행동을 예측하고, 부정적 건강 행동을 바꾸는데 목표를 둔 설득적인 의사소통 기술을 발 전시키고 이해하는데 적용되고 있다(Conner \& Norman, 2005). 즉, 보호동기이론에서 위험지각은 건강행동을 선 택하는데 중요하게 작용하는 동기적 요인으로 간주되며, 어떤 행동으로부터 초래될 가능성이 있는 결과에 대한 개 인 또는 집단의 판단과 평가라는 의미로 정의된다(Weinstein, 1980).

신체활동 연구에서 위험지각은 규칙적인 신체활동을 시작하고 유지하는데 있어 중요한 기능을 하는 것으로 보 고되고 있다(Brewer et al., 2007). Schwarzer(2008)는 위험지 각이 청소년들의 신체활동 참여를 설명하는데 중요한 역 할을 한다고 지적하면서, 아울러 생애주기적 관점에서 청 소년기는 다양한 건강행동을 경험하고 학습하는 과정이 빈번하게 발생하는 시기에 해당됨에 따라, 이 시기동안 청소년들은 신체활동에 대한 건강상의 이득과 손실에 대 한 지각성향을 습관화할 가능성이 매우 높다고 주장하였 다.

사람들은 자신들의 개인적인 위험이나 질병에 대해 예측할 때 낙관적으로 편향되는 경향이 있다 (Weinstein, 1982). 낙관적 편향이란 사람들이 어떤 질병에 대한 자신 의 위험 가능성을 자신과 비슷한 연령의 다른 이들보다 낮게 보려는 경향을 의미한다 (Weinstein, 1989). 예를 들 어, 운동부족으로 인해 발생할 수 있는 다양한 질병(예: 심 장병, 비만, 당뇨병)에 대한 낙관적이거나 비현실적인 지 각은 건강위험을 줄이려는 노력을 하지 않 게 만들 가능성 이 있다. Brewer와 동료들 (2007)은 신체활동에 대한 개인
의 지각성향은 앞으로 신체활동에 참여할 가능성을 설명 하는데 있어 유의한 예측변인이라고 주장하였다. 특히, 이 연구에서 신체활동부족으로 인한 건강위험에 대해 잘 못된 낙관적 편향을 가진 청소년들은 실제적으로 규칙적 인 신체활동 참여율이 감소하였을 뿐만 아니라, 이로 인 해 나타날 수 있는 건강위험에 대헤서도 잘못된 지각성 향을 보이는 것으로 보고되었다. 또한, Stephan 등 (2011) 은 규칙적으로 운동을 하지 않는 청소년들이 미래에 건강 상의 위험이나 질병에 걸릴 가능성이 높다고 지각하는 것 은 그들이 운동부족으로 인한 건강위험을 피하기 위해 규 칙적으로 운동에 참여하도록 운동의도를 자극한다고 지 적하면서 건강위험지각은 청소년들의 신체활동 참여의 도에 유의한 영향을 준다고 주장하였다. 그러나 위험지 각이 신체활동 참여의 동기 및 의도와의 유의한 관련성에 대한 연구결과와는 대조적으로, 몇몇 연구들은 신체활동 과 위험지각 간에 유의한 관련성이 없다고 주장하고 있 다(Courneya \& Hellsten, 2001; Plonitikoff, Thinh, Courneya, Karunamuni, \& Sigal, 2009). 이와 같은 선행연구들의 상반 되는 연구결과들로 인해 일부 연구자들은 신체활동을 예 측하고 설명하는데 있어 위험지각의 유의성에 의문을 제기하고 있다(Plontikoff, Rhodes, \& Trihn, 2009). 그러나 이들 연구 대부분은 횡단적 설계에 의해 수행되었거나 (Plontikoff \& Higginbotham, 2002), 또는 비록 실험설계 방 식을 적용하였더라도, 사용된 중재전략이 운동부족과 관 련된 건강위험에 초점을 맞춘 구체적인 위험정보를 제공 하기 보다는 단순히 신체활동을 통해 건강을 증진시키는 것과 관련된 정보만을 제공하였다(Lee \& Kim, 2015; Saffari et al., 2013).

운동부족 관련 건강위험정보 제공 전략(health risk information strategy)을 적용한 몇몇 선행연구에 따르면, 이 전략은 신체활동부족과 관련된 여러 가지 질병(예, 심장 병, 비만, 당뇨병 등)에 대한 개인의 위험지각 능력을 향 상시키는데 있어 유의한 효과가 입증되었다(Grover et al., 2007; McGowan \& Prapavessis, 2010). 또한, Milne, Orbell, Sheeran (2002)은 청소년들에 게 심장병과 비만 등에 관한 건강위험 메시지를 제공하는 것만으로도 건강위험지각 능력을 고양시키는데 효과가 있으며, 이를 통해 고양된 위험지각은 규칙적인 신체활동에 하고자 하는 의도에 영 향을 주어 실제로 신체활동 참여가 증가되는 결과를 가져 온다고 주장하였다. 그러나 이들 연구들은 대부분 국외에 서 수행되었으며, 특히 청소년들을 대상으로 운동부족관 
련 건강위험정보제공 전략을 적용한 국내연구는 전무한 실정이다. 따라서 위험지각과 신체활동 간에는 유의한 관 련성이 있으며, 심장병, 비만, 당뇨병이 신체활동부족으 로 인해 가장 빈번하게 발생하는 질병이라는 선행연구들 을 토대로, 본 연구는 신체활동부족 관련 건강위험 정보 제공전략이 질병(심장병, 비만, 당뇨병)에 대한 위험지각 에 주는 효과를 확인하고, 이러한 위험지각 변화와 신체 활동의 변화 사이의 관련성을 검증하는데 목적이 있다.

\section{연구 방법}

\section{연구대상}

본 연구에 참여한 청소년들은 서울시 $\mathrm{N}$ 구에 소재한 $\mathrm{H}$ 중학교 남학생들 중, 현재 전혀 신체활동을 하지 않고 있 는 학생들을 예비 연구참여자 $(\mathrm{n}=314)$ 로 선정하였다. 예 비 연구참여자들과 그들의 부모들에 게 연구의 취지와 연 구방법 등을 설명한 연구참여동의서를 배부하고 자발적 인 참여를 요청하였다. 이 과정에서 총 46 명의 학생들이 그들 자신과 부모의 동의서를 제출하였으며, 이들을 대 상으로 총 12 주간의 건강위험정보제공 프로그램을 실시 하였다. 학생들은 프로그램 참여 기간 동안 3 차례에 걸쳐 운동부족 관련 건강위험지각과 관련된 변인들을 측정하 였다. 프로그램 시작 전에 46 명의 참여자들을 대상으로 1 차 검사를 실시하였고, 프로그램 적용 6주 후에 실시한 2 차 검사에는 $86.9 \%(\mathrm{n}=40$ 명 $)$ 의 학생들이 참여하였으며, 최종적으로 $80.4 \%(\mathrm{n}=37)$ 의 학생들이 12 주간의 프로그램 에 참여하였다.

\section{측정도구}

건강위험자각 연구참여자들의 신체활동부족과 관련된 건강위험에 대한 지각을 측정하기 위하여 Health Vulnerability Measure(Bassett \& Martin-Ginis, 2011)를 한국어로 표 준화한 한국판 운동부족 건강위험지각 질문지를 사용하 였다. 이 질문지는 신체활동부족과 관련된 대표적인 질 환(심장병, 비만, 당뇨병)에 대해 7점 리커트 척도(-3 = '매 우 그렇지 않다' 부터 $3=$ '매우 그렇다')로 응답하였다. 예 를 들면, "당신에게 (a) 심장병, (b) 비만, (c) 당뇨병이 발 생할 가능성은 어느 정도입니까?” 이 질문지에서 비활 동성과 관련된 질환의 선정은 신체활동부족 및 관련 질 환에 대한 선행연구들의 결과를 기초로 하였다(Milne, et al., 2002; Stephan, Boiche, Trouilloud, Deroche, \& Sarrazin,
2011). 한국판 측정도구의 신뢰도는 확인하기 위하여 사 전연구가 수행되었으며, 이러한 과정을 통해 이 측정도구 의 test-retest $\mathrm{r}=.90$ 으로 나타났다.

객관적 위험인자 지표 신체활동부족과 관련된 질환에 대한 객관적 위험인자를 평가하기 위한 지표는 연구참 여자들의 신체구성과 혈액검사 결과를 토대로 결정되었 다: (1)체질량지수 (body mass index), (2)허리둘레, (3)포도 당, (4)인슐린, (5)C-반응성 단백질. 체질량 지수는 체중 $(\mathrm{kg}) / ㅋ ㅣ(\mathrm{~m})^{2}$ 로 계산되었으며, 이를 위해 체성분분석기(Inbody Co., 한국)를 사용하였다. 허리둘레는 참가자들이 반 듯이 누운 상태에서 정상 날숨 이후 가슴밑 흉골의 주위 를 따라 측정되었다. 포도당, C-반응성 단백질과 인슐린 은 연구참여자의 혈 액분석을 통해 측정되었다. 이러한 객 관적 건강위험의 지표 검사는 연구참여자들을 위험군과 비위험군으로 구분하는 기준으로 사용되었다: (1)체질량 지수(체중 $(\mathrm{kg}) /$ 키 $(\mathrm{m})^{2}:>25.0,(2)$ 허리둘레(허리둘레 $(\mathrm{cm}) /$ 신장 $(\mathrm{cm})):>0.47,(3) \mathrm{C}$-반응성 단백질 $(\mathrm{mg} / \mathrm{L}):>3.0,(4)$ 포도 당 $(\mathrm{mmol} / \mathrm{L}):<3.8$ 또는 $>6.0,(5)$ 인슐린 $(\mathrm{pmol} / \mathrm{L})$ : <43.0 또 는 >194.0.

신체활동량 연구참여자들의 신체활동량은 Godin과 Shephard (1985)의 Leisure Time Physical Activity Questionnaire를 Kim, Cardinal, Lee(2006)이 한국어로 번역하여 표 준화한 한국판 여가시간 신체활동 질문지를 사용하여 측 정하였다. 이 질문지는 2 문항으로 구성되어 있다. 첫 번 째 문항은 "당신은 지난 1 주일(7일) 동안 자유(여가) 시 간에 평균적으로" 강한 강도의 운동 “(심장이 빨리 고 동치는 수준), 중간 강도의 운동” (지치지 않는 수준), 그 리고 “약한 강도의 운동” (여유있는 수준)을 몇 번 정 도 최소 20 분 이상 하였습니까? "라는 질문으로 연구참 여자들은 자신이 수행한 각기 다른 강도의 횟수를 직접 기입한다(예, 만약 지난 1 주 일에 20 분 이상 빠르게 자전 거타기를 4 번하고, 지치지 않을 정도로 수영을 3 번하였다 면,” 강한 강도의 운동 “에 ‘ 4 ' , "중간 강도의 운동” 에 ‘0’ , 그리고 “약한 강도의 운동” 에 ‘3’ 으로 기입한 다). 두 번째 문항은 “당신은 지난 1주일(7일) 동안 자유( 여가) 시간에 얼마나 자주 심장이 빨리 뛰고 땀이 나는 수 준의 운동에 규칙적으로 참여하였습니까?” 라는 질문으 로, 반응범위는 “자주 하였다” (1)에서부터 “전혀 또는 별로 하지 않았다” (3)까지의 3점 척도이다. 응답한 신체 
활동 점수는 총 MET(metabolic equivalent) 값을 구하기 위 하여 각 운동강도별로 곱해져서 합산된다[예: (강한강도 의 운동횟수 $\times 9)+($ 중간강도의 운동횟수 $\times 5)+($ 약한강도 의 운동횟수 $\times 3)]$. Kim et al.(2006)은 운동수준 질문지의 testretest 신뢰도를 .82로 보고하였다.

\section{운동부족 관련 건강위험정보 제공 전략 연구최근 들어} 신체활동연구 영역에서 건강위험정보 제공 전략(Health risk message intervention)은 위험정보에 대한 지각, 실제 신체활동 및 참여의도의 변화에 대한 효과를 강화시키 기 위한 전략으로 개발되었다(Albada, Ausems, Bensings, \& van Dulmen, 2009; Noar, Benac, \& Harris, 2007). 신체활동 연구에서 이 전략은 개인의 신체활동 부족의 원인이 무엇 이든 간에 이와 관련된 건강위험 또는 질병에 관한 정보 를 제공하는 것은 신체활동부족에 관한 경각심을 증가시 키고 건강위험지각 편견을 감소시키는데 유의하게 작용 한다는 것을 전제로 하고 있다. 구체적으로, 건강위험정 보 제공 전략은 신체활동부족으로 인한 건강위험에 대한 지식증가 및 현실적인 위험지각 능력 향상, 그리고 실제 적인 신체활동의 변화에 도움을 주는데 초점이 맞추어져 있다. 특히, 신체활동 촉진전략으로써 건강위험정보의 제공은 행동변화를 위한 효과적인 메시지를 제공하여 실 제적인 행동변화의 가능성을 향상시킬 수 있다(Latimer et al., 2010). 여기서 행동변화 메시지는 주어진 행동과 대상 이 된 건강위험과의 관계에 대한 정보를 제공하는 것을 말한다. 예를 들어, 심장 질환에 대한 위험의 증가에 대한 정보가 제공된 후, 행동변화 메시지는 규칙적인 신체활 동과 심장질환 감소의 유의한 관계를 보여주는 것이 될 수도 있다.

건강위험정보 제공 전략에서 메시지 구조화 (Message Framing)가 신체활동 행동변화 메시지의 효과를 향상시 키기 위한 핵심적인 방법으로 사용된다. 메시지 구조화 는 규칙적인 신체활동 참여의 이점(혜택 구조화 메시지) 과 규칙적인 신체활동에 참여하지 않는 것의 위험성(손 실 구조화 메시지)의 차이에 대한 전략적인 내용들을 포 함하고 있다. 예는 들어 “규칙적인 신체활동에 참여함으 로써 당신은 비만의 위험성을 줄일 수 있다” 는 혜택 구 조화 메시지의 예에 해당되며, "규칙적인 신체활동에 참 여하지 않음으로써 당신은 심장병의 위험성을 증가시키 고 있다" 는 손실 구조화 메시지에 해당된다. 비록 이 메 시지들이 문맥상 동일하고 그 차이가 미묘하게 보일지라
도, 사람들은 메시지 구조에 따라 다르게 반응한다는 결 과들이 선행 연구들에 의해 보고되고 있다. 이러한 건강 위험정보 제공전략은 Bassett과 Martin-Ginis(2011)의 연구 에서 사용된 자료들을 근거로 한다.

\section{연구절차}

본 연구의 참여자로 선정된 학생들은 건강위험정보제 공 프로그램을 실시하기 전에 일반적 특성(연령, 신장, 몸 무게), 연구변인(신체활동량, 위험지각, 체질량지수, 허리 둘레, C-반응성 단백질, 포도당, 인슐린)을 측정하였다. 사전조사가 완료된 후, 연구참여자들은 12 주 동안 1 주일 에 2회, 총 24회의 프로그램에 참여하였다. 이 프로그램 은 오전 8 시부터 8 시 40 분까지 1 회 40 분씩 S중학교 교실 을 이용하여 실시되었다. 프로그램 종료 후, 연구참여자 들은 프로그램을 적용하기 전과 동일하게 일반적 특성과 연구변인을 측정하였다. 연구참여자들의 참여율을 유지 하고 참여의지를 높이기 위해서 주 1 회 주말을 이용하여 참여학생과 부모들에 게 다음 주 프로그램의 목표와 내용 등을 소개하는 문자를 발송하였다. 본 연구의 모든 과정 은 연구책임자 소속 학교의 연구위원회 승인을 받아 수 행되었다.

\section{자료처리}

건강위험정보제공 중재전략이 연구참여자들의 운동 부족 관련 객관적 건강위험(심장병, 비만, 당뇨병)의 지각 에 효과가 있는지를 확인하기 위하여 2(위험군 vs 비위험 군) $\mathrm{x} 2$ (중재전략 전 vs 중재전략 후) 반복측정 분산분석이 수행되었다. 또한, 심장병, 비만, 당뇨병에 대한 위험지각 의 변화가 건강위험정보제공 중재전략 적용 전, 후, 신체 활동의 변화를 예측하는지를 검증하기 위하여 3 개의 개 별적 위계적 회귀분석이 실시되었다. 각 회귀모델에서 중 재전략적용 전의 위험지각이 첫 번째 단계에 입력되었으 며, 두 번째 단계에서 중재전략 적용 후의 위험지각이 분 석모형에 입력되었다. 본 연구의 모든 분석은 SPSS 23.0을 이용하여 수행되었다.

\section{결 과}

\section{건강위험정보제공 중재전략의 효과}

운동부족 관련 질병(심장병, 비만, 당뇨)의 위험지각 에 대한 건강위험 정보제공 전략의 효과와 객관적 위험 
Table 1. Results of Repeated Measure ANOVA Comparing Perceived Risk of Heart Disease by Time and Objective Risk Status

\begin{tabular}{|c|c|c|c|c|c|}
\hline \multirow[b]{2}{*}{$\begin{array}{l}\text { Objective heart disease } \\
\text { risk factor }\end{array}$} & \multicolumn{2}{|c|}{ Perceived health risk } & \multirow[b]{2}{*}{$\begin{array}{c}\text { Time } \\
F \\
\left(\text { partial } n^{2}\right)\end{array}$} & \multirow[b]{2}{*}{$\begin{array}{c}\text { Objective risk } \\
F \\
\left(\text { partial } \eta^{2}\right)\end{array}$} & \multirow[b]{2}{*}{ Time $\times$ Objective risk $\mathrm{F}\left(\right.$ partial $\left.\eta^{2}\right)$} \\
\hline & $\begin{array}{l}\text { Baseline } \\
\text { M(SD) }\end{array}$ & $\begin{array}{l}\text { Post- } \\
\text { intervention } \\
M(S D)\end{array}$ & & & \\
\hline Waist circumference & & & $11.45^{* *}(0.17)$ & $4.72^{*}(0.09)$ & $2.89(0.05)$ \\
\hline At risk & $-0.32(1.61)$ & $1.10(0.96)$ & & & \\
\hline Not at risk & $-0.89(1.81)$ & $-0.50(1.76)$ & & & \\
\hline BMI & & & $8.72^{* * *}(0.15)$ & $0.48(0.01)$ & $1.23(0.03)$ \\
\hline At risk & $-0.49(1.53)$ & $0.20(1.27)$ & & & \\
\hline Not at risk & $-0.76(1.90)$ & $-0.36(1.91)$ & & & \\
\hline C-reactive protein & & & $4.82^{*}(0.11)$ & $0.01(0.00)$ & $0.03(0.00)$ \\
\hline At risk & $-0.31(2.07)$ & $0.04(2.00)$ & & & \\
\hline Not at risk & $-0.91(1.98)$ & $-0.10(1.85)$ & & & \\
\hline
\end{tabular}

Table 2. Results of Repeated Measures ANOVA Comparing Perceived Risk of Obesity by Time and Objective Risk Status

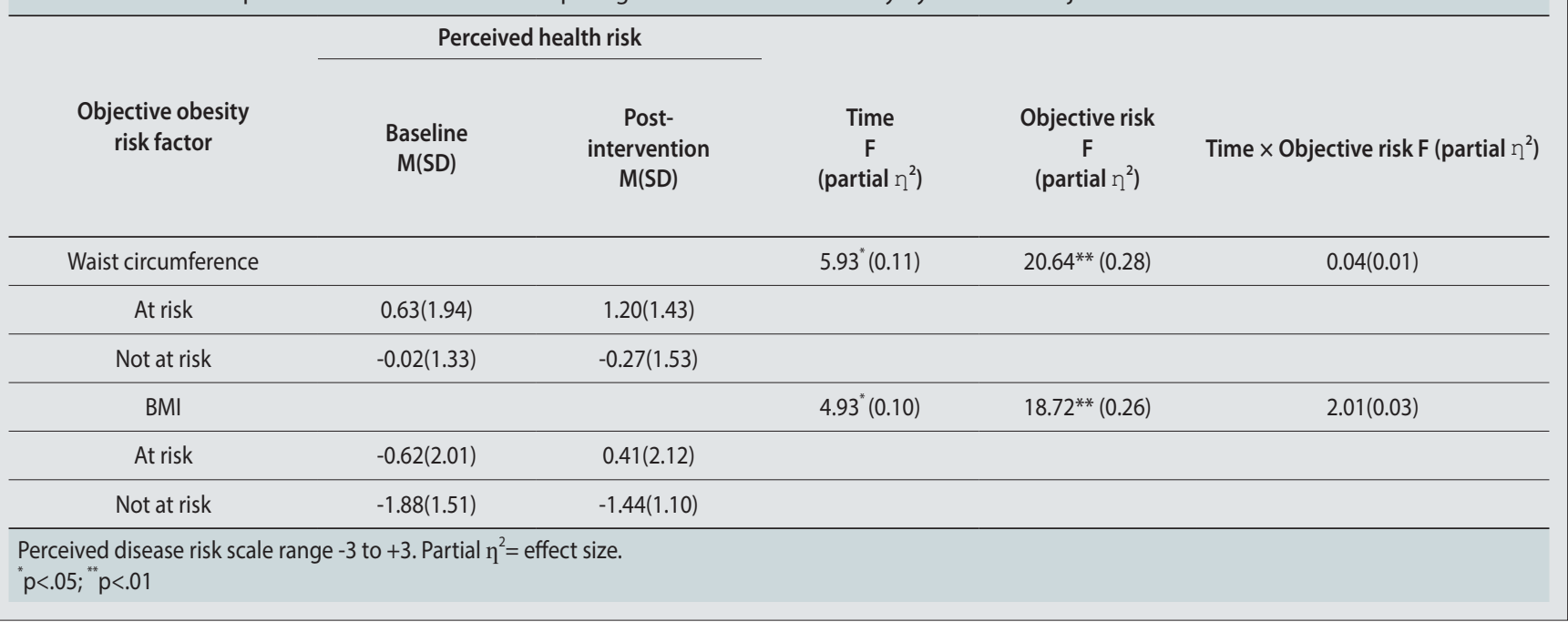

인자의 조절효과를 알아보기 위하여 집단(위험군 vs 비 위험군 $) \times$ 측정시기(중재전략 전 vs 중재전략 후) 반복 측정 분산분석이 수행되었다(Table 1-3). <Table 1>에 따 르면, 심장병의 위험지각에 대해 허리둘레는 측정시 기 $\left[\mathrm{F}(1,39)=11.45, \mathrm{p}<.01 ;\right.$ partial $\left.\mathrm{n}^{2}=.17\right]$ 와 객관적 위험 $\left[\mathrm{F}(1,39)=4.72, \mathrm{p}<.05 ;\right.$ partial $\left.\eta^{2}=.09\right]$ 에 유의한 주효과가 있 는 것으로 나타났으며, $\mathrm{BMI}[\mathrm{F}(1,39)=8.72, \mathrm{p}<.01$; partial $\left.\mathrm{n}^{2}=.15\right]$ 와 $\mathrm{C}$-반응성 단백질 $[\mathrm{F}(1,39)=4.82, \mathrm{p}<.05$; partial $\mathrm{n}^{2}=.11$ ]은 측정시기에 대해서만 유의미한 주효과가 있는 것으로 나타났다, 즉, 건강위험 정보제공 전략은 위험여 부와 관계없이 위험군과 비위험군 모두의 건강위험지각 을 향상시키는 데 유의한 영향을 주었다.

<Table 2>는 비만에 대한 위험지각을 종속변인으로 한 반복측정 분산분석의 결과를 보여주고 있다. 객관적 비 만인자로써 허리둘레는 측정시기 $(\mathrm{F}(1,39)=5.93, \mathrm{p}<.05$; partial $\left.\eta^{2}=.11\right)$ 와 객관적 위험 $(\mathrm{F}(1,39)=20.64, \mathrm{p}<.01$; partial 


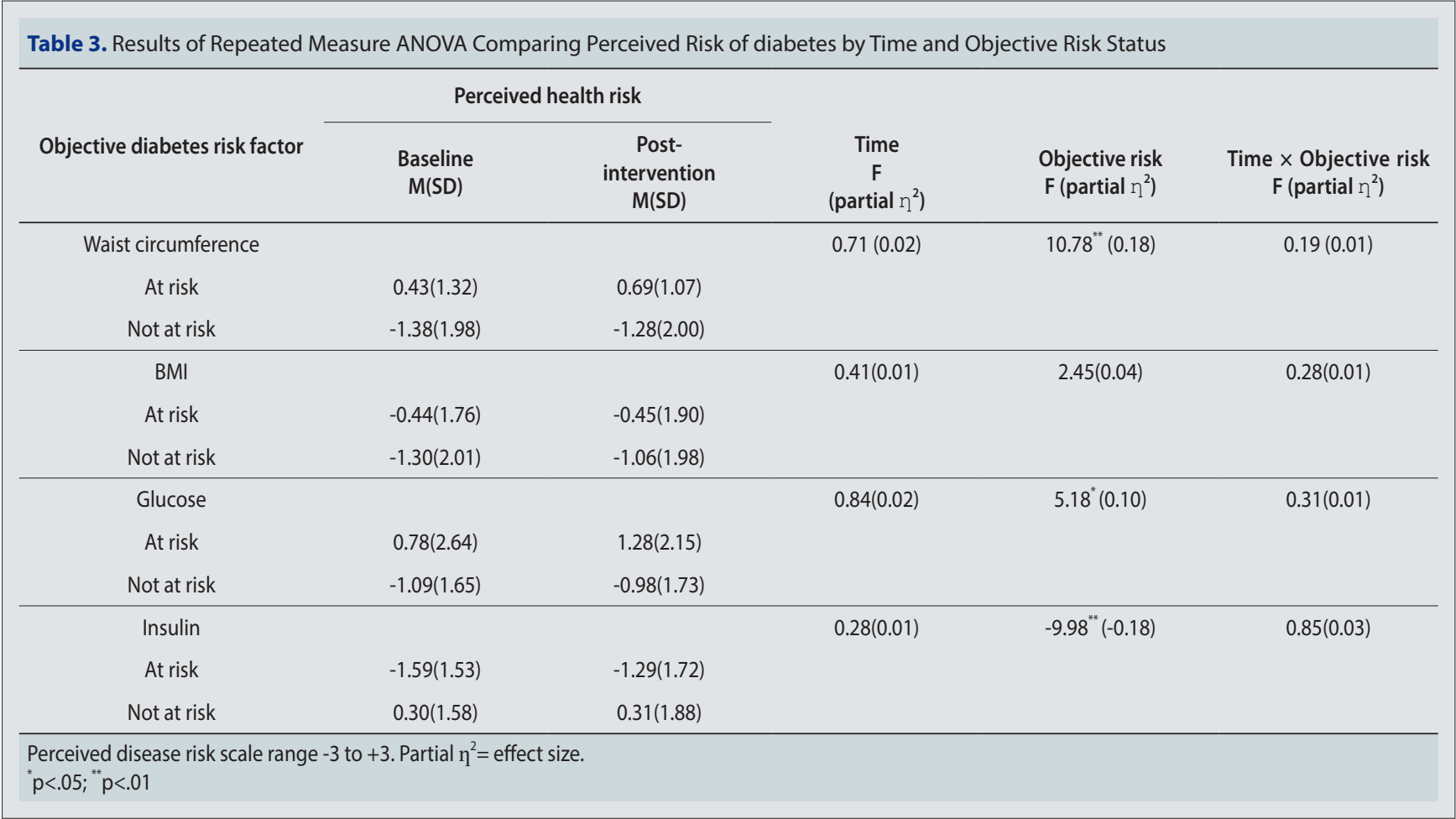

$\mathrm{n}^{2}=.28$ )에 대해 유의한 주효과가 있는 것으로 나타났다. 또한, $\mathrm{BMI}$ 도 측정시기 $\left(\mathrm{F}(1,39)=4.93, \mathrm{p}<.05 ;\right.$ partial $\left.\eta^{2}=.10\right)$ 와 객관적 위험 $\left(\mathrm{F}(1,39)=18.72, \mathrm{p}<.01\right.$; partial $\left.\mathrm{n}^{2}=.26\right)$ 에 대 해 유의한 주효과가 있는 것으로 보고되었다. 즉, 비만에 대해 위험군은 전반적으로 자신들이 더 큰 위험에 처해 있다고 지각하고 있으며, 또한, 위험여부에 상관없이 위 험군과 비위험군 모두 비만에 대한 건강위험지각이 중재 전략을 통해 증가하였다.

<Table 3>은 당뇨병에 대한 위험지각을 종속 변인으 로 한 반복측정 분산분석 결과를 보여 주고 있다. 객관적 인 당뇨병 위험인자들 중에서, 허리둘레 $(\mathrm{F}(1,39)=10.78$, $\mathrm{p}<.01$; partial $\left.\eta^{2}=.19\right)$, 포도당 $(\mathrm{F}(1,39)=5.18, \mathrm{p}<.05$; partial $\left.\eta^{2}=.10\right)$, 인슐린 $\left(\mathrm{F}(1,39)=-9.88, \mathrm{p}<.01 ;\right.$ partial $\left.\eta^{2}=-.18\right)$ 이 위 험군과 비위험군 간에 객관적 위험에 대해 유의한 주효과 가 있는 것으로 나타났다.

\section{건강위험지각과 신체활동변화의 관련성}

건강위험지각은 신체활동의 변화를 예측하는지를 확인하기 위하여 각 운동부족 관련 객관적 위험인자별 로 위계적 회귀분석을 실시하였으며, 그 결과는 <Table $4>$ 와 같다. 심장병에 대한 위험지각은 신체활동의 변화
( $\beta=-.37, \mathrm{p}<.05)$ 에 유의한 영향을 미치는 것으로 나타났 으며, 이 회귀모형에서 건강위험지각은 신체활동의 변화 $(\mathrm{F}(3,37)=3.43, \mathrm{p}<.05)$ 를 예측하는데 $19 \%$ 의 설명력이 있는 것으로 나타났다 $\left(\mathrm{f}^{2}=.19\right)$. 또한, 비만에 대한 위험지각은 중재전략 적용 이전부터 이후까지 신체활동의 변화에 지 속적으로 유의한 영향을 주는 것으로 나타났다 ( $\beta=.31$, $\mathrm{p}<.05$ in the 1st step, $\beta=.39, \mathrm{p}<.05$ in the 2nd step). 이 회귀모 형에서 건강위험지각은 신체활동의 변화 $(\mathrm{F}(2,38)=3.67$, $\mathrm{p}<.05)$ 를 예측하는데 $22 \%$ 의 설명력이 있는 것으로 나타 났다 $\left(\mathrm{f}^{2}=.22\right)$. 당뇨에 대한 위험지각의 변화는 신체활동 의 변화 $(\beta=.38, \mathrm{p}<.05)$ 에 유의한 영향을 미치는 것으로 나 타났다. 이 회귀모형에서 건강위험지각은 신체활동의 변 화 $(\mathrm{F}(5,35)=3.37, \mathrm{p}<.05)$ 를 예측하는데 $10 \%$ 의 설명력이 있 는 것으로 나타났다 $\left(\mathrm{f}^{2}=.10\right)$.

\section{논 의}

본 연구는 신체활동부족 관련 건강위험 정보 제공전 략이 질병(심장병, 비만, 당뇨병)에 대한 위험지각에 주는 효과를 확인하고, 이러한 위험지각 변화와 신체활동의 변 화사이의 관련성을 검증하기 위하여 수행되었다. 


\begin{tabular}{|c|c|c|c|c|}
\hline Perceived health risk variables & $\mathrm{R}^{2}$ & $\mathrm{R}^{2} \Delta$ & $\beta$ & $f^{2}$ \\
\hline Heart disease & & & & 0.14 \\
\hline Step 1 & 0.03 & 0.03 & & \\
\hline Perceived risk T1 & & & 0.16 & \\
\hline Step 2 & 0.13 & 0.11 & & \\
\hline Perceived risk T1 & & & $0.28^{*}$ & \\
\hline Perceived risk $T 2$ & & & $-0.37^{*}$ & \\
\hline Obesity & & & & 0.22 \\
\hline Step 1 & 0.14 & 0.14 & & \\
\hline Perceived risk T1 & & & $0.31^{*}$ & \\
\hline Step 2 & 0.12 & 0.01 & & \\
\hline Perceived risk T1 & & & $0.39^{*}$ & \\
\hline Perceived risk T2 & & & -0.09 & \\
\hline Diabetes & & & & 0.10 \\
\hline Step 1 & 0.02 & 0.02 & & \\
\hline Perceived risk T1 & & & 0.07 & \\
\hline Step 2 & 0.09 & 0.07 & & \\
\hline Perceived risk T1 & & & $-0.20^{*}$ & \\
\hline Perceived risk T2 & & & $0.38^{*}$ & \\
\hline
\end{tabular}

본 연구에서 신체활동부족 관련 질병 중, 심장병과 비 만의 위험군에 속한 청소년들은 건강위험 정보제공 전략 이 제공된 후에 허리둘레와 $\mathrm{BMI}$ 에 대한 위험지각이 유의 하게 증가한 것으로 나타났다. 이러한 결과들은 여러 선 행연구들에 의해 지지되고 있으며 (Bassett \& Martin-Ginis, 2011; Li, Ng, Cheng, \& Fung, 2017), 신체활동부족으로 인한 건강위험에 대한 정보는 이로 인한 대표적인 질병으 로 알려진 심장병 및 비만 등의 객관적 위험인자의 지표 가 높은 위험군에 속한 사람들의 질병위험에 대한 인식 을 높이는데 효과적인 방법이라고 설명될 수 있다. 특히 흥미로운 점은 신체활동부족 관련 질병에 대한 위험지각 의 긍정적인 변화는 객관적 위험인자의 지표가 낮은 비위 험군에 속하는 청소년들에게도 나타났다는 것이다. 예를 들어, 비만의 객관적 위험인자인 허리둘레가 건강위험수 준에 처해 있지 않은 청소년들도 중재전략 적용 후에 비 만에 대한 위험지각이 유의하게 증가하였으며, 이러한 결 과 또한 선행연구에 의해 지지되었다(Grover et al., 2007). 이러한 결과들은 본 연구에 적용한 신체활동부족 관련 건 강위험 정보제공 전략은 운동부족으로 인한 질병의 위험
군 과 비위험군 사람들 모두의 낙관적이거나 부정확한 위 험인식을 줄이는데 효과적이라는 해석을 가능하게 한다.

흥미롭게도, 당뇨병에 대한 위험지각은 어떠한 객관적 위험인자에서도 객관적 위험이나 위험에 대한 피드백의 기능으로써 유의하게 영향을 주지 않았다. 이러한 결과에 대해 본 연구에서 사용한 건강위험 정보 전략 중, 허리둘 레, BMI, 단백질, 인슐린에 대한 내용은 연구 참여자들이 당뇨병에 대한 위험을 지각하는데 유용한 정보를 제공하 지 못했을 것으로 추측된다. 특히, 당뇨병의 비위험군에 속한 청소년들과 비교하여 위험군에 있는 청소년들은 중 재전략이전과 이후 모두 당뇨병에 대해 위험지각이 높은 것으로 나타났다. 이에 대한 해석으로 이들은 자신들이 당뇨병 위험이 높다는 것을 이미 인식하고 있으며, 중재 전략에 포함된 당뇨병 위험정보들은 그들이 이미 알고 있 는 내용 정도였을 수 있기 때문에, 그들이 가지고 있는 당 뇨병에 대한 건강위험의 인식이 바뀔 가능성은 거의 없을 것으로 예측했을 것으로 판단된다(천장 효과).

본 연구는 위험지각의 변화가 신체활동의 변화를 예측 하는데 있어 신체활동부족 관련 건강위험 정보제공 전략 
이 어떠한 영향을 주는 지를 확인하였다. 중재전략을 통 해 심장병에 대한 위험지각이 증가한 청소년들의 신체활 동은 감소한 것으로 나타났다. 비록 이 결과는 보호동기 이론의 가설과는 상반되지만(Rogers, 1983), 몇몇 연구에 의해 지지되고 있다(Plontikoff \& Higginbotham, 2002). 이 러한 결과에 대해, 심장병에 대한 위험지각이 증가한 청 소년들은 아마 그에 대한 두려움도 함께 증가했을지도 모 른다. 이러한 두려움은 어떤 사람들에 게는 두려움을 일으 키는 건강위험에 관한 정보를 회피하거나 부정하는 등의 부정적 대처 반응으로 이어졌을 수도 있을 것이다(Conner \& Norman, 2005). 더욱이, 본 연구에서 적용된 중재전 략은 연구 참가자들에게 신체활동에 대한 구체적인 정보 (예, 건강이득 및 중요성 등)를 제공하지 않았기 때문에, 심장병에 대한 위험지각이 증가한 연구 참여자들은 신체 활동이 주는 이점에 대한 지식이 부족했거나, 신체활동에 참여하는 것이 오히려 심장병에 더 부담을 주는 위험요인 으로 인식하여 두려워했을지도 모른다.

또한, 비만과 당뇨병에 대한 위험지각의 변화는 신체 활동의 변화에 유의한 영향을 주는 것으로 나타났다. 중 재전략 전부터 비만과 당뇨병에 대한 위험지각이 높았던 청소년들은 운동부족 관련 건강위험 정보제공 전략을 적 용한 이후에도 더욱 활발하게 신체활동에 참여한 것으로 나타났다. 특히, 비만과 관련된 결과에 대해 비만과 관련 된 객관적 위험인자(허리둘레, $\mathrm{BMI}$ )들은 일반적으로 측 정 및 관찰이 가능하기 때문에, 본 연구에 참여한 많은 연 구 참여자들은 중재전략 적용 전에 이미 자신들의 비만 위험에 대해 지각하고 있었을 지도 모른다. 따라서 중재 전략을 통해 연구 참여자들에 게 자신의 비만위험에 대해 생각해 보라고 하는 것이 신체활동에 대한 동기를 부여 하는데 긍정적으로 작용했을 수도 있다. 이와 같은 해석 은 위험지각의 증가는 신체활동을 포함한 다양한 건강 관 련 행동의 증가와 연관되어 있다는 이전 연구들에서 지 지되고 있다(Floyd, Prentice-Dunn, \& Rogers. 2000; Milne et al., 2000).

본 연구에서 얻어진 결과는 특정 위험요인에 관한 정 보는 다른 것들보다 위험을 지각하는데 더 큰 영향을 미 칠 수 있다는 것을 보여준다. 예를 들어, 허리둘레 및 $\mathrm{BMI}$ 는 비만의 중요한 위험요인이라는 것이 대중매체를 통해 빈번하게 강조되고 있기 때문에, 청소년들은 이러한 위험 요소에 관해 잘 이해하고 있으며, 따라서 허리둘레와 BMI 는 청소년들이 비만의 위험을 지각하는데 유의하게 영향
을 주었을 것이다. 반면, C-반응성 단백질과 인슐린과 같 은 건강위험 요소들은 비만의 위험을 인식하는데 있어 의 미 있는 피드백을 제공하지 못하거나 간과될 수 있다. 예 를 들어, C-반응성 단백질과 인슐린의 경우, 본 연구에 참 여한 청소년들은 아마도 이들 건강위험 요소들과 비만관 련 질병의 관련성에 대해 잘 알지 못하거나, 심지어 이들 위험요소 자체의 의미를 이해하지 못할 지도 모른다. 뿐 만 아니라, 허리둘레나 $\mathrm{BMI}$ 는 직접 육안으로 관찰이 가 능하지만, C-반응성 단백질과 인슐린은 육안으로 직접 확 인할 수 없는 위험요소이기 때문에, 허리둘레나 BMI를 통 해서 자신의 비만 위험을 지각하는 것이 용이할 것이다.

본 연구에서 얻어진 유의한 연구결과에도 불구하고 다 음과 같은 몇 가지 제한점들은 신중히 고려되어야 할 것 이다. 첫째, 신체활동과 심리적 변인들이 신뢰성과 타당 성이 검증된 표준화된 측정도구에 의해 측정되었지만, 질 문지에 의한 자기보고식 방법이 사용되었으므로 문항해 석의 오류나 사회적 요망 편견 등의 문제가 발생할 수 있 다. 둘째, 본 연구는 단일집단 시계열조사를 적용한 준실 험설계 연구이다. 따라서 통제집단을 두지 않은 연구에서 나타난 결과가 절대적으로 건강위험정보 전략의 효과인 지, 또는 다른 요인 (예, 사전조사로 인한 학습효과, 성장 및 성숙 등)에 의해 영향을 받은 것인지를 정확하게 확인 하는데 문제가 있을 수 있다.

본 연구에서 얻어진 결과는 신체활동의 예측변수로써 건강위험지각에 대해 이론적이고 실용적인 시사점을 모 두 제공한다. 즉, 청소년들이 신체활동부족 관련 특정질 환(심장병, 비만, 당뇨)에 대한 위험지각이 신체활동의 중 요한 예측변수가 될 수 있다는 것을 확인하였다. 이것은 보호동기이론의 이론적 유의성에 해당하는 것이며, 이러 한 결과는 규칙적인 신체활동 참여를 통해 예방이 가능한 질병들의 위험지각은 신체활동 참여를 증가시킬 확률이 가장 높다는 것을 의미한다. 또한, 실제적인 측면에서 청 소년들에 게 질병과 신체활동 사이의 관련성을 이해하게 하는 것이 그 질병에 대한 건강위험 정보가 신체활동을 하도록 동기를 부여하는데 핵심일 것이다. 따라서 이러한 결과는 건강증진 및 예방의학 분야에서 심장병, 비만, 당 뇨와 같은 신체활동부족과 연관된 질병의 위험을 줄이기 위해서는 신체활동의 장점과 동시에 운동부족에 기인한 건강위험을 적극적으로 홍보할 필요가 있음을 시사한다. 


\section{Acknowlegdement}

이 논문은 2015년 대한민국 교육부와 한국연구재단의 지 원을 받아 수행된 연구임(NRF-2015S1A5A2A03048588).

\section{Conflicts of Interest}

The authors declare no conflict of interest.

\section{References}

Albada, A.1., Ausems, M.G., Bensing, J.M., \& van Dulmen, S. (2009). Tailored information about cancer risk and screening: a systematic review. Patient Education and Counselling, 77, 155171.

Brewer, N.T., Chapman, G.B., Gibbons, F.X., Gerrard, M., McCaul, K.D., \& Weinstein, N.D. (2007). Meta-analysis of the relationship between risk perception and health behavior: the example of vaccinations. Health Psychology, 26, 136-145.

Bassett, R.L. \& Martin-Ginis, K.A. (2011). Risky business: The effects of an individualized health information intervention on health risk perceptions and leisure time physical activity among people with spinal cord injury. Disability and Health Journal, 4, 165-176

Courneya, K.S. \& Hellsten, L.A.M. (2001). Cancer prevention as a source of exercise motivation: an experimental test using protection motivation theory. Psychology, Health \& Medicine, 6, 59-64.

Conner, M. \& Norman, P. (2005). Predicting health behavior. 2nd ed. New York: Open University Press.

Davidson, K. \& Prkachin, K. (1997). Knowledge changes optimism and unrealistic optimism have an interacting impact on health-promoting behavior and knowledge changes. Personality and Social Psychology Bulletin, 23, 617-625.

Duncan, S.C., Duncan, T.E., Strycker, L.A., \& Chaumeton, N.R. (2007). A cohort-sequential latent growth model of physical activity from ages 12 to 17 years. Annals of Behavioral Medicine, 33(1), 80-89.

Floyd DL, Prentice-Dunn S, \& Rogers RW. (2000). A meta-analysis of research on protection motivation theory. Journal of Applied Social Psychology, 30(2), 407-429.
Godin, G., \& Shephard, R. J. (1985). A simple method to assess exercise behavior in the community. Canadian Journal of Applied Sport Science, 10, 141-146.

Grover, S.A., Lowensteyn, I., Joseph, L., Kaouache, M., Marchand, S., Coupal, L., \& Bouodreau, G. (2007). patient knowledge of coronary risk profle improves the effectiveness of dyslipidemia therapy: the CHECK-UP study: a randomized controlled trail. Archives of Internal Medicine, 167, 2296-2303.

Kim, Y. H., Cardinal, B. J., \& Lee, J. Y. (2006). Understanding exercise behavior among Korean adults: A test of the transtheoretical model. International Journal of Behavioral Medicine, 13, 295-303.

Kim, Y.H. (2011). Adolescents' health behavior and its associated psychological variables. Central European Journal of Public Health, 19, 206-210.

Latimer, A. E., Rench, T. A., Rivers, S. E., Katulak, N. A., Materese, S. A., Cadmus, L. \& Salovey, P. (2008). Promoting participation in physical activity using framed messages: An application of prospect theory. British Journal of Health Psychology, 13, 659-681.

Latimer, A.E., Brawley, L.R., \& Bassett, R.L. (2010). A systematic review of three approaches for constructing physical activity messages: what messages work and what improvements are needed? International Journal of Behavioral Nutrition and Physical Activity, 7, 36-53.

Lee, H.G. \& Kim, Y.H. (2015). Effects of an obesity intervention integrating physical activity and psychological strategy on BMI, physical activity, and psychological variables in male obese adolescents. Behavioral Medicine, 41, 195-202.

Li, K.K., Ng, L., Cheng, S.T., \& Fung, H.H. (2017). Reverse message-framing effects on accelerometer-assessed physical activity among older outpatients with type 2 diabetes, Journal of Sport and Exercise Psychology, 39, 222-227.

Milne S, Sheeran P, Orbell S. (2000). Prediction and intervention in health-related behavior: a meta-analytic review of protection motivation theory. Journal of Applied Social Psychology. 30(1), 106-143.

Milne, S., Orbell, S., \& Sheeran, P. (2002). Combining motivational and volitional interventions to promote exercise participation: protection motivation theory and implementation intentions. British Journal of Health Psychology, 7, 163-184. 
McGowan, E.L. \& Prapavessis, H. (2010). Colon cancer information asa a source of exercise motivation for relatives of patients with colon cancer. Psychology, Health \& Medicine, 15, 729741.

Noar, S.M., Benac, C.N., \& Harris, M.S. (2007). Does tailoring matter? Meta-analytic review of tailored print health behavior change interventions. Psychological Bulletin, 133, 673-693.

Plontikoff, R.C. \& Higginbotham, N. (2002). Protection motivation theory and exercise behaviour change for the prevention of heart disease in a high-risk, Australian representative community sample of adults. Psychology, Health \& Medicine, 7, 87-98.

Plontikoff, R.C., Thinh, L., Courneya, K.S., Karunamuni, N., \& Sigal. R.J. (2009). Predictors of aerobic physical activity and resistance training among Canadian adults with type 2 diabetes: an application of the protection motivation theory. Psychology of Sport and Exercise, 10, 320-328.

Plontikoff, R.C., Rhodes, R.E., \& Trihn, L. (2009). Protection motivation theoty and physical activity: a longitudinal test among a representative population sample of Canadian Adults. Journal of Health Psychology, 14, 1119-1134.

Rogers, R.W. (1983). Cognitive and physiological processes in fear appeals and attitude change: A revised theory of protection motivation. In: Cacioppo, J.R., Petty, R,E, eds. Social Psychology: A Source book. New York: Guilford.
Schwarzer, R. (2008). Modeling health behavior change: How to predict and modify the adoption and maintenance of health behaviors. Applied Psychology, 57, 1-29.

Seoul City Education Office (2009). Student evaluation document. Seoul city education office.

Stephan, Y., Boiche, J., Trouilloud, D., Deroche, T., \& Sarrazin, P. (2011). The relation between risk perceptions and physical activity among adolescents: a prospective study. Psychology \& Health, 26, 887-897.

Saffari, M., Amini, N., Eftekhar A.H., Sanaeinasab, H., Mahmoudi, M., \& Piper, C.N. (2013). Educational intervention on health related lifestyle changes among Iranian adolescents. Iranian Journal of Public Health, 42(2), 172-181.

U.S. Center for Disease Control and Prevention (2012). Youth risk behavior surveillance. United States, 2010. Mortality and Morbidity Weekly Report, 53, 1-95.

Weinstein, N. D. (1980). Unrealistic optimism about future life events. Journal of Personality and Social Psychology, 39, 806-820.

Weinstein, N.D. (1982). Unrealistic optimism about susceptibility to health problems. Journal of Behavioral Medicine., 5, 441-460.

Weinstein, N.D. (1989). Optimistic biases about personal risk. Science. 246, 1232-1233.

Weinstein ND. (2007). Misleading tests of health behavior theories. Annals of Behavioral Medicine. 33(1), 1-10. 